\title{
Need of Old Age Homes: A Sociological Study in Srinagar District (JK)
}

\author{
Dr Humaira Showkat \\ Assistant Professor (Research), UNESCO Madanjeet Singh Institute of Kashmir Studies, \\ University of Kashmir \\ humairashowkat@yahoo.com
}

\begin{abstract}
There is a common view, generally, that the aged in India enjoy power, authority, respect and security. The social status of an elderly person is determined by several factors such as physical health, economic status, marital status, level of education, position in the society, etc. However, with the advent of industrialization there has been a significant change in the family system in particular and social structure in general. Joint families disintegrated and small nuclear families emerged where the young couple finds no time to look after their old parents. In such families the position of the old has become a crucial factor. The old themselves find it difficult to adjust with the modern ways of living of their young children.

In this backdrop the present study is an endeavor to investigate and explore the emerging problems of elderly in Indian society in general and Srinagar city $(\mathrm{JK})$ in particular. The study is primarily based on survey method and observation among various areas of Srinagar city of Jammu \& Kashmir State. Among the Kashmiris, the family had a special significance. It is a primary group that is considered to be nearest, dearest and intimate of all groups. This group is always accessible and ready to offer help in times of crisis. Be it a financial or emotional or any other type of help, and there is always a feeling that it is a duty and in fact a privilege to volunteer such a help. The family as a group is more important than the individual members who constitute the group. The main functions of the family mainly were procreation of new members and maintenance of old members but now it has lost this role. The impact of modern society has declined this holism to a certain degree. It is seen in the present study that a section of Kashmiri society has undergone changes owing to the modern waves. This change of traditional family system to modern system is the direct reflection of commercialization, monetization and urbanization of the Indian economy and society.
\end{abstract}

Human life, in all its stages, is blessed with growth and development which in later stages results in ageing. Ageing is a multi dimensional phenomenon and is associated with physical, psychological and socio economic factors. Ageing of population is a phenomenon in all the countries. Different sociologists and psychologists have defined the concept of ageing or elderly in their own way. Some emphasize on chronology and others on physical capabilities. However, it is also subject to the constructions by which each society makes sense of old age. In the developed world, chronological time plays a paramount role. The age of 60 or 65 , roughly equivalent to retirement ages in most developed countries is said to be the beginning of old age. In many parts of the developing world, chronological time has little or no importance in the meaning of old age. Other socially constructed meanings of age are more significant such as the roles assigned to older people. Thus, in contrast to the chronological milestones which mark life stages in the developed world, old age in many developing countries is seen to begin at the point when active contribution is no longer possible (Gorman, 2000).

Therefore, in view of the above discussion, the definition of old age could be understood under the three main categories:

1) Chronology;

2) Change in social role (i.e. change in work patterns, adult status of children and menopause); and

3) Change in capabilities (i.e. invalid status, senility and change in physical characteristics).

The problems of ageing have drawn the attention of national and international organizations only in the last three or four decades. Though from the 16th century, several European authors have made systematic thinking about the patterns, process and meaning of ageing( gerontology) and also made efforts to ameliorate, control and prevent the various problems of the aged (Saxena,2006:5). The first journal devoted to the study of ageing, the Journal of Gerontology was started in 1946. India's eighth 


\section{Dr Humaira Showkat}

five year plan has sought to encourage voluntary or nongovernmental organizations to provide old age homes, day care centers, mobile medical units and other programmes benefiting the elderly through grants of aid (Saxena,2006:12). The successful ageing is not only achieved through policies and other beneficiary programmes but individual and society both have to play an important role. In other words the problems of aged are to be looked from all perspectives be it at Governmental level, societal level or individual level. It will be in place to mention here the WHO slogan that "it is not sufficient to add years to life but the more important objective is to add life to years".

The problems of the aged are discussed all over the world and particularly in the developed countries. Most of the developed countries have implemented various welfare measures for the security of their senior citizens. The United Nations general assembly adopted principles for elderly persons on $16^{\text {th }}$ December 1991 to encourage government to design their own policies and programmes in this regard. The guiding principles of this resolution were: independence, participation, care and self fulfillment (Saxena, 2006:114-115). The United Nations declared the year 1999 as the "International year of old persons". In India, the national policy for older person was announced by central government in January 1999. The goal of the policy is the well being of older persons. It, mainly, aims to strengthen their legitimate place in society and helps them live their life with purpose, dignity and peace. According to Lawrence Cohen (2003), "Since 1970s, gerontological writing in India has been dominated by a powerful and seldom challenged narrative of the decline of the Indian joint family and the consequent emergence of old age as a time of difficulty" (Arvind, 2006:21). Furthermore Mishra (1987) states that the impact of industrialization, westernization and urbanization has weakened the integrity of joint family that leads to the negligence of the role and status of elderly persons. As a result old people take step forward to join old age homes. As per the recent data there are about 1018 old age homes in India. The elderly population in India as per 2011 census is $7.08 \%$ i.e. 71697634.

Every individual plays different roles according to the stages in his life. During the childhood, the early adulthood, middle adulthood, they are supposed to play roles of son/daughter, husband/wife, father/mother, grandfather/grandmother etc. In this regard Moody suggests the story of the baby bird who rides on her mother's back while the mother searches for food. One day the mother asks the baby bird when I am old and frail, will you carry me on your back just as I am doing now?oh no mother replies baby bird, I'll carry my own baby bird just as you are doing now. The moral of this folklore is that no matter what the older generation has done for the younger, each generations primary obligation is transitive (Rajagopal,2006:222). Ageing is a natural phenomenon that refers to changes that occur during life and result in differences in structure and function between younger and older generation. In Hindu tradition the "Vanaprastha Ashram" is considered the stage of old age once they have fulfilled the duties and responsibilities to the family, they retire from active life and move to hermitage (Pappathi, 2007:9-10). The Indian census has adopted 60 years for classifying a person as old (Pappathi, 2007:57).

One's position in social structure affects his personality. There is considerable diversity among norms and aspirations of people, as they are grouped in different classes along loosely structured class lines. Views of the aged and ageing among different religious, ethnic and cultural subgroups influence the ageing process. In this regard Emile Durkheim writes, "so long people of any class, age, gender and creed are closely knitted with social bond, they are hale and hearty and feel lesser the pinch of ageing in case of senior citizens. The moment the senior citizens feel socially isolated and disintegrated from social bond, they begin to experience fast ageing which becomes a problem" (Saxena, 2006:4). Therefore every society has its own conception of ageing and age grouping. Through the process of socialization, the society ensures the transmission of social and cultural values from one generation to the next and enables its members to acquire necessary skills, values, norms etc. as the individual moves from one age-grade to next; he acquires new roles in accordance with the prevailing practices. Age related roles, privileges and expectations are defined by society.

There is a common view, generally, that the aged in India enjoy power, authority, respect and security. The social status of an elderly person is determined by several factors such as physical health, economic status, marital status, level of education, position in the society, etc. However, with the advent of industrialization there has been a significant change in the family system in particular and social structure in general. Joint families disintegrated and small nuclear families emerged where the young couple finds no time to look after their old parents. In such families the position of the old has become a crucial factor. The old themselves find it difficult to adjust with the modern ways of living of their young children. In the cities where there is growth of individualism and with it the 
desire to be self- reliant, the clashes between generations distress the old. Many of the problems faced by the urban elderly do not exist in the villages. Therefore a good number of elderly from urban group have taken resource to old age homes. The present study aims at highlighting the one main yardstick and that is need for old age homes for elderly population of Srinagar city. The work is primarily based on field work conducted during June 2012-Aug 2013 in different areas of Srinagar. The survey method has been used for the study. The methods of data collection were interview schedule and observation. Interview schedule comprised 24 questions which had major options as yes or no. Sampling method has been used to select respondents from the city of Srinagar. A sample of 150 respondents was drawn. Non probability judgment and quota sampling technique has been used in the study. The respondents were split in terms of socio- demographic variables like income, education, occupation, gender, age, area, marital status. The number of the respondents are further categorized which is shown in figure below

\section{Description of sample}

Total no of sample $(\mathrm{N})=\mathbf{1 5 0}$

Male population $(M)=79$, Female population $(F)=71$
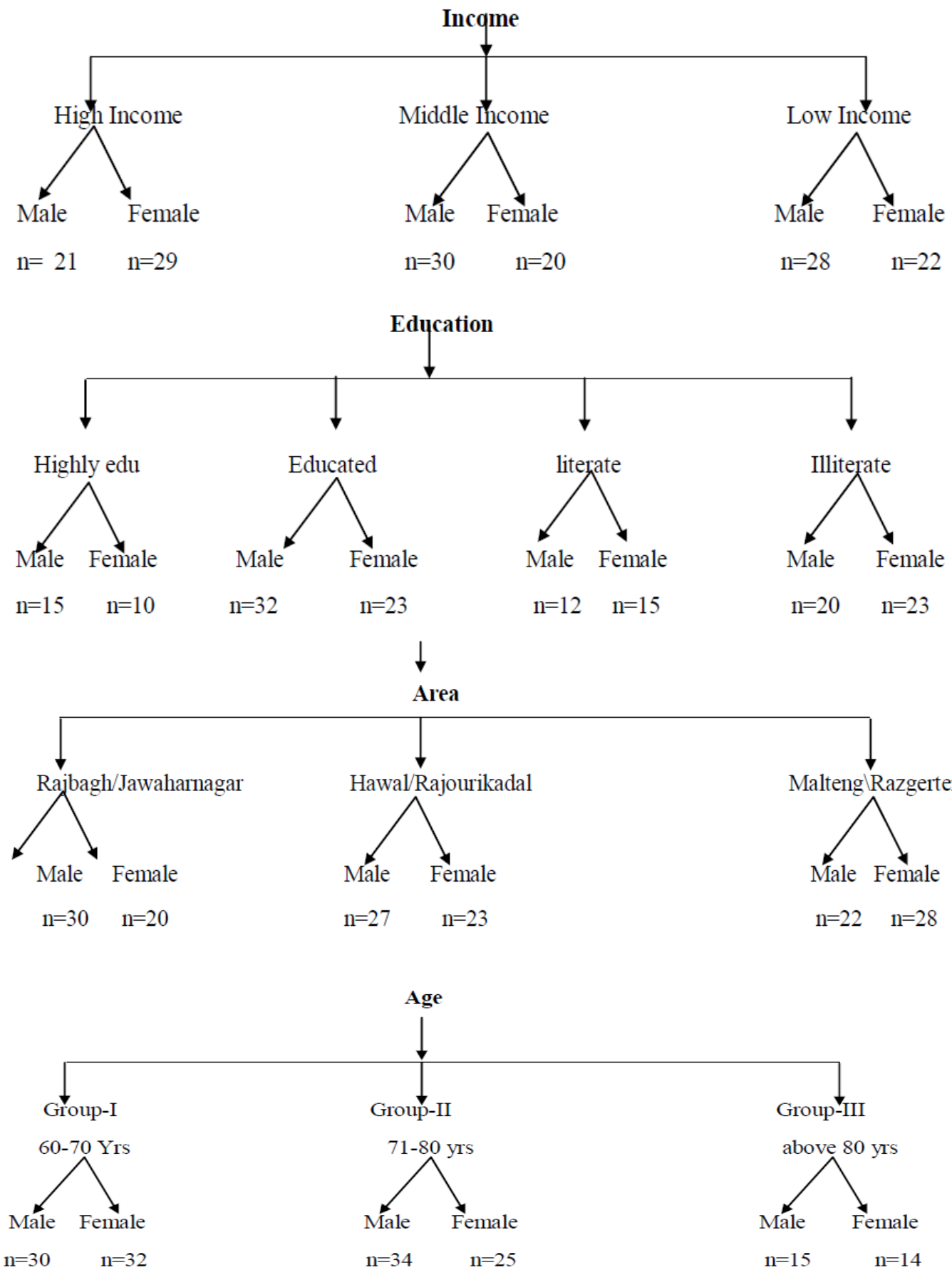


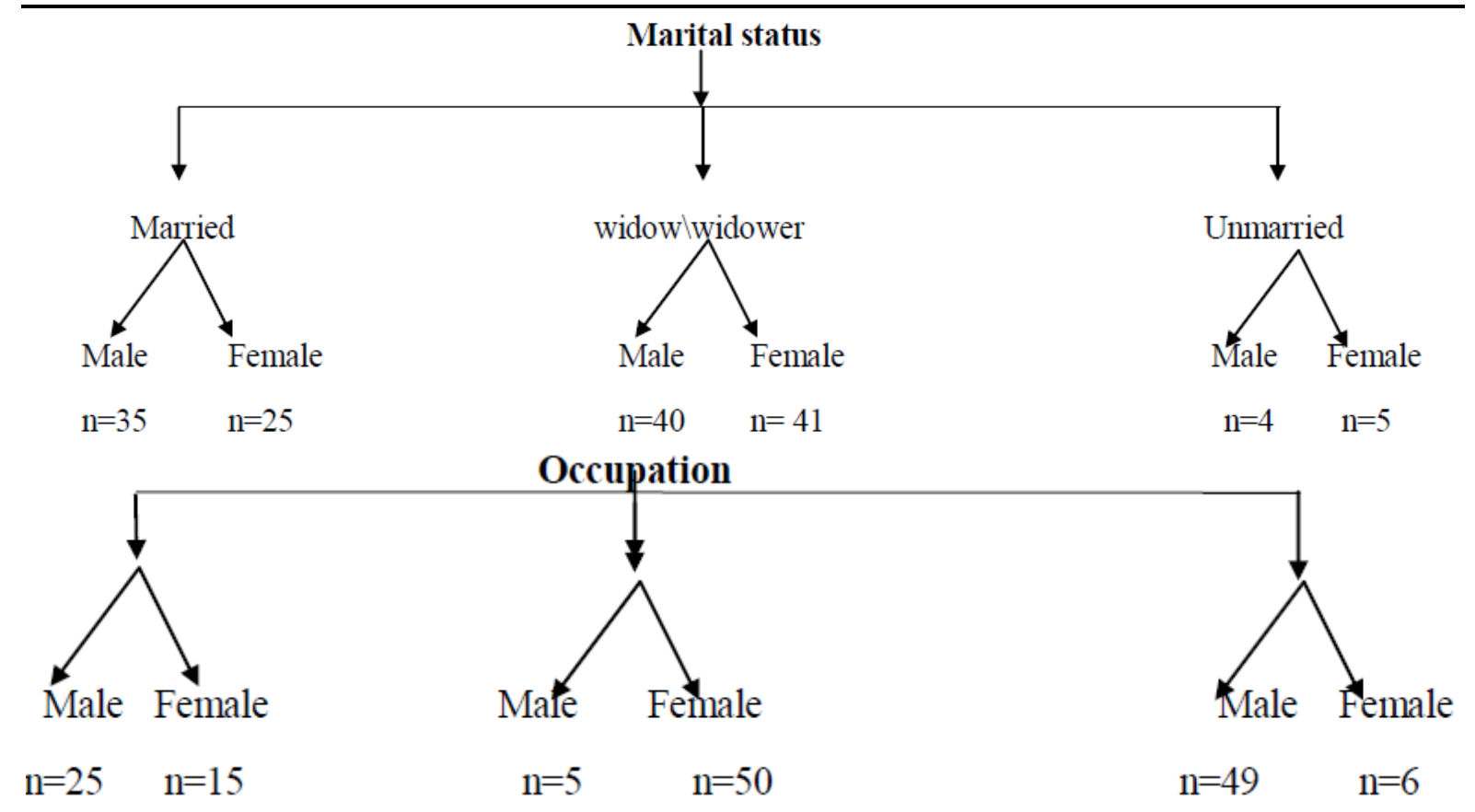

For quantification and analysis of the collected data the procedure of percentage analysis has been used. The following research has been made on quantitative basis. After completing the investigation and recording the interview, the processing of data was initiated. Percentages of the responses were calculated. From tabulated data, inferences have been drawn.

Srinagar city represents heterogeneous elderly population belonging to different socio-economic strata. The population has been categorized on the basis of income, occupation, education, gender, marital status, area and age. This heterogeneity of elderly in Srinagar city enables the researcher to trace out the differences in attitude of respondents towards the problems faced by elderly.

Data, collected during the field work and percentage obtained from responses highlight the extent of problems of elderly emerging in Srinagar city which is shown in the form of tables and figures. Field study, as mentioned earlier, was carried out during June 2012 - Aug 2013. Schedule was used for data collection from 150 respondents. The breakup of respondents' colony wise is as follows.
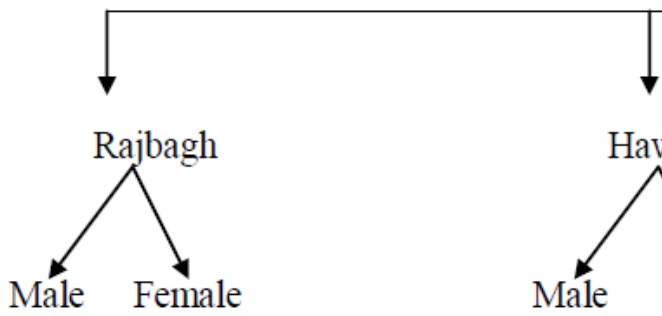

$n=30 \quad n=20$

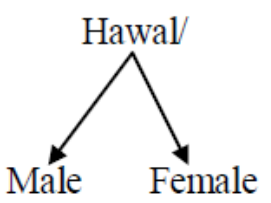

$n=27 \quad n=23$

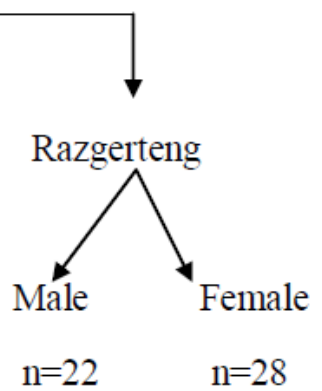

$n=22$

$$
\mathrm{n}=28
$$

\section{Need of Old Age Homes}

The need for the establishment of old age homes is the important yardstick of the present study. The elders feel that their respect and dignity etc will be secured in such a place. Findings of the study explore the fact that old age homes/day care centers are need of the hour, especially for the elderly living without their children and having least interaction with neighbors, relatives, and friends etc. Also, in some cases elderly from nuclear families, where there are working women, need such a place for their day and daily care. Tables indicate that the elderly belonging to upper income group need old age homes due to many reasons like loneliness, least interaction and are even ready to pay for these homes. The majority of elderly especially from middle and lower income groups wants to stay with their families. This is the consequence of the fact that the elderly from former group have least interaction with family, neighbours or relatives and thus want to stay anywhere where there is someone who can talk with them. Although the care which they are getting at home from their servants is enough for their sustenance but in order to enjoy their remaining life, it is imperative for them to share their ideologies. Living in old age homes or day care centers will help them to interact 
with the people of their genre. Thus an old age home, day care centers is the need of Kashmiri society in general. Old age home will not only serve the need of proper care but it is a way to entertain and share and make their life happy in a healthy environment. Tables reveal the responses of respondents.

Table1. Income Criterion

\begin{tabular}{|l|l|l|l|l|l|l|}
\hline Class & \multicolumn{2}{|c|}{$\mathbf{N}^{*}=\mathbf{1 5 0}$} & Male & Female & No \\
\hline & $\mathbf{M}=\mathbf{7 9}$ & $\mathbf{F}=\mathbf{7 1}$ & Yes & No & Yes & No \\
\hline Upper & $\mathrm{M}=21$ & $\mathrm{~F}=29$ & $18(85.7 \%)$ & $3(14.2 \%)$ & $20(68.9 \%)$ & $9(31.03 \%)$ \\
\hline Middle & $\mathrm{M}=30$ & $\mathrm{~F}=20$ & $10(33.34 \%)$ & $20(66.66 \%)$ & $9(45 \%)$ & $11(55 \%)$ \\
\hline Lower & $\mathrm{M}=28$ & $\mathrm{~F}=22$ & $8(28.5 \%)$ & $20(71.4 \%)$ & $2(9.09 \%)$ & $20(90.9 \%)$ \\
\hline
\end{tabular}

Table 1 depicts that out of 21 respondents from upper income males $85.7 \%$ agree that old age homes is need of present society and $14.2 \%$ do not .In case of upper income females, out of 29 respondents $68.9 \%$ accepts the need of old age homes and $31.03 \%$ do not. Among the middle income males, out of 30 respondents, $33.34 \%$ agreed and $66.66 \%$ do not. So far as the females from middle income group are concerned, out of 20 respondents, $45 \%$ favour the need of old age homes and $55 \%$ do not. Further table shows among low income males, out of 28 respondents, $28.5 \%$ favours and $71.4 \%$ do not and out of 22 females from low income group, 9.09\% need old age homes and 90.9\% do not need.

Table1.1. Education Criterion

\begin{tabular}{|l|l|l|l|l|l|l|}
\hline Education & \multicolumn{1}{|c|}{$\mathbf{N}^{*}=\mathbf{1 5 0}$} & & \multicolumn{1}{|c|}{ Male } & & \multicolumn{1}{c|}{ Female } & \\
\cline { 2 - 7 } Highly educated & $\mathbf{M}=\mathbf{7 9}$ & $\mathbf{F} * \mathbf{7 1}$ & Yes & No & Yes & No \\
\cline { 2 - 7 } & $\mathrm{M}=15$ & $\mathrm{~F}=10$ & $10(66.66 \%)$ & $5(33.34)$ & $3(30 \%)$ & $7(70 \%)$ \\
\hline Educated & $\mathrm{M}=32$ & $\mathrm{~F}=23$ & $15(46.8 \%)$ & $17(53.12)$ & $15(65.2 \%)$ & $8(34.7 \%)$ \\
\hline Literate & $\mathrm{M}=12$ & $\mathrm{~F}=15$ & $6(50 \%)$ & $6(50 \%)$ & $8(53.3 \%)$ & $7(46.6 \%)$ \\
\hline Illiterate & $\mathrm{M}=20$ & $\mathrm{~F}=23$ & $5(25 \%)$ & $15(75 \%)$ & $5(21.73 \%)$ & $18(78.27 \%)$ \\
\hline
\end{tabular}

Table 1.1 conveys that out of 15 respondents from highly educated males $66.66 \%$ need old age homes and $33.34 \%$ do not. In case of highly educated females, out of 10 respondents $30 \%$ agreed with the same view and $70 \%$ do not. Among the educated males, out of 32 respondents, $46.8 \%$ agreed $53.12 \%$ do not. So far as the females from educated group are concerned, out of 23 respondents, $65.2 \%$ agreed and $34.7 \%$ do not. Further table shows among literate males, out of 12 respondents, $50 \%$ agreed and $50 \%$ do not and out of 15 females from literate group, 53.3\% agreed and $46.6 \%$ do not. Again we can see from the table that out of 20 males from illiterate group, 25\% need old age home and $75 \%$ do not. And $21.73 \%$ females from the same group need old age homes and $78.27 \%$ do not.

Table1.2. Occupation Criterion before Superannuation

\begin{tabular}{|l|l|l|l|l|l|l|}
\hline \multirow{2}{*}{ Occupation } & \multicolumn{2}{|c|}{$\mathbf{N}^{*}=\mathbf{1 5 0}$} & \multicolumn{2}{c|}{ Male } & \multicolumn{2}{l|}{ Female } \\
\hline $\begin{array}{l}\text { Working in Govt/ } \\
\text { Private sector }\end{array}$ & $\mathbf{M}=\mathbf{7 9}$ & $\mathbf{F}=\mathbf{7 1}$ & Yes & No & Yes & No \\
\hline Non-working & $\mathrm{M}=25$ & $\mathrm{~F}=15$ & $15(60 \%)$ & $10(40 \%)$ & $9(60 \%)$ & $6(40 \%)$ \\
\hline $\begin{array}{l}\text { Business/ Personal or } \\
\text { Associated }\end{array}$ & $\mathrm{M}=5$ & $\mathrm{~F}=50$ & $2(40 \%)$ & $3(60 \%)$ & $20(40 \%)$ & $30(60 \%)$ \\
\hline
\end{tabular}

Table 1.2 ascertains that out of 25 respondents who have worked in govt or private sector, $60 \%$ need old age home and $40 \%$ do not need. In case of females from the same group, out of 15 respondents $60 \%$ need and $40 \%$ do not. Among the non working males, out of 5 respondents, $40 \%$ agree with the same view and $60 \%$ do not. So far as the females from the same group are concerned, out of 50 respondents, $40 \%$ agree that old age home is dearth of contemporary society and $60 \%$ do not agree. Further table shows among the business class males, out of 49 respondents, $38.77 \%$ agree and $61.22 \%$ do not and out of 6 females from the same group, 33.34\% feel that old age home is need of Kashmiri society and $66.66 \%$ do not.

Table1.3. Age Criterion

\begin{tabular}{|l|l|l|l|l|l|l|}
\hline Age & \multicolumn{2}{|c|}{$\mathbf{N}^{*}=\mathbf{1 5 0}$} & \multicolumn{2}{c|}{ Male } & \multicolumn{2}{c|}{ Female } \\
\hline \multirow{3}{*}{ Group I 60-70 } & $\mathbf{M}^{*}=\mathbf{7 9}$ & $\mathbf{F}^{*}=\mathbf{7 1}$ & Yes & No & Yes & No \\
\cline { 2 - 7 } & $\mathrm{M}=30$ & $\mathrm{~F}=32$ & $10(33.33 \%)$ & $20(66.67 \%)$ & $10(31.25 \%)$ & $22(68.75 \%)$ \\
\hline Group II 70-80 & $\mathrm{M}=34$ & $\mathrm{~F}=25$ & $18(52.94 \%)$ & $16(47.05 \%)$ & $12(48 \%)$ & $13(52 \%)$ \\
\hline Group III 80\& above & $\mathrm{M}=15$ & $\mathrm{~F}=14$ & $8(53.33 \%)$ & $7(46.66 \%)$ & $9(64.28 \%)$ & $5(35.72 \%)$ \\
\hline
\end{tabular}




\section{Dr Humaira Showkat}

Table 1.3 conveys that out of 30 male respondents from group I, $33.33 \%$ feel the need of old age homes and $66.67 \%$ do not feel. In case of females from the same group, out of 32 respondents $31.25 \%$ agreed there is need of old age home and $68.75 \%$ do not agree. Among the males from group II, out of 34 respondents, $52.94 \%$ need old age home and $47.05 \%$ do not. So far as the females from group II are concerned, out of 25 respondents, $48 \%$ agreed and 52\% do not. Further table shows among males from group III, out of 15 respondents, $53.33 \%$ agreed and $46.66 \%$ do not and out of 14 females from the same group, $64.28 \%$ feel need of old age homes and $35.72 \%$ do not. females from the same group, $20 \%$ feel need of old age home and $80 \%$ do not.

Table1.4. Area as Criterion

\begin{tabular}{|l|l|l|l|l|l|l|}
\hline Area & \multicolumn{2}{|c|}{$\mathbf{N}^{*}=\mathbf{1 5 0}$} & \multicolumn{2}{c|}{ Male } & \multicolumn{2}{c|}{ Female } \\
\hline \multirow{3}{*}{ Rajbagh } & $\mathbf{M}^{*}=\mathbf{7 9}$ & $\mathbf{F}^{*}=\mathbf{7 1}$ & Yes & No & Yes & No \\
\cline { 2 - 7 } & $\mathrm{M}=30$ & $\mathrm{~F}=20$ & $16(53.3 \%)$ & $14(46.66 \%)$ & $10(50 \%)$ & $10(50 \%)$ \\
\hline Hawal & $\mathrm{M}=27$ & $\mathrm{~F}=23$ & $10(37.04 \%)$ & $17(62.96 \%)$ & $10(43.4 \%)$ & $13(56.5 \%)$ \\
\hline Razgerteng & $\mathrm{M}=22$ & $\mathrm{~F}=28$ & $10(45.4 \%)$ & $12(54.5 \%)$ & $11(39.29 \%)$ & $17(60.71 \%)$ \\
\hline
\end{tabular}

Table 1.4 depicts that out of 30 respondents from Rajbagh area, 53.3\% feel need of old age home and $46.66 \%$ do not feel. In case of females from the same group, out of 20 respondents $50 \%$ feel need and $50 \%$ do not. Among the males from Hawal area, out of 27 respondents, $37.04 \%$ feel need and $62.96 \%$ do not. So far as the females from the same area are concerned, out of 23 respondents, $43.4 \%$ agree that old age home is need of present society and $56.5 \%$ do not agree. Further table shows among the males of Razgerteng area, out of 22 respondents, $45.4 \%$ feel need of old age home and $54.5 \%$ do not and out of 28 females from the same area, $39.29 \%$ feel need and $60.71 \%$ do not.

Table1.5. Marital Status as Criterion

\begin{tabular}{|l|l|l|l|l|l|l|}
\hline Marital Status & \multicolumn{2}{|c|}{$\mathbf{N}^{*}=\mathbf{1 5 0}$} & \multicolumn{2}{c|}{ Male } & \multicolumn{2}{c|}{ Female } \\
\hline \multirow{3}{*}{ Married } & $\mathbf{M}^{*}=\mathbf{7 9}$ & $\mathrm{F}^{*}=\mathbf{7 1}$ & Yes & No & Yes & No \\
\cline { 2 - 7 } & $\mathrm{M}=35$ & $\mathrm{~F}=25$ & $12(34.28 \%)$ & $23(65.72 \%)$ & $10(40 \%)$ & $15(60 \%)$ \\
\hline Widow/Widower & $\mathrm{M}=40$ & $\mathrm{~F}=41$ & $24(60 \%)$ & $16(40 \%)$ & $20(48.78 \%)$ & $21(51.22 \%)$ \\
\hline Unmarried & $\mathrm{M}=4$ & $\mathrm{~F}=5$ & $0(0.00 \%)$ & $4(100 \%)$ & $1(20 \%)$ & $4(80 \%)$ \\
\hline
\end{tabular}

Table 1.5 shows that out of 35 married male respondents, $34.28 \%$ agree that old age home is essential for elderly people and $65.72 \%$ do not. In case of females from the same group, out of 25 respondents $40 \%$ feel need and $60 \%$ do not. Among the widower males, out of 40 respondents, $60 \%$ agreed with the same view and $40 \%$ do not agree. So far as the widow females are concerned, out of 41 respondents, $48.78 \%$ agree and $51.22 \%$ do not. Further table shows among unmarried males, out of 4 respondents, no one feel need of old age home and out of 5 females, 20\%agrees and $80 \%$ does not.

\section{DISCUSSION}

History reveals that different societies have undergone changes at different stages like, in the cases of, ancient society into feudal society, feudal society into capitalist society, military into industrial society, traditional society into modern society. Modernization is one of the important factors of social change. Modernization is not a philosophy or a movement with a clearly articulated value system rather it is a process of change. As a consequence of change in economy, the society simultaneously underwent changes in values, beliefs and norms. Today, the term modernization is given a broader meaning. It is described as "social change involving the elements of science and technology". However, sociologists examine it in terms of 'differentiation in quality of life' that characterizes the modern societies. They explore new structures created to perform new functions and/or new functions assigned to old structures. Indian society at the time of independence had a deep rooted tradition but it also wanted to become modern. There were people who wanted a traditional way of life; there were others who wanted to see India emerge as a modern state having no links with the past. There were yet others who were for some kind of compromise or synthesis between tradition and modernity. Modernization as far as Yoginder Singh is concerned goes along with traditions in Indian society. He said that there is traditionalization of modernization and modernization in Indian traditions (Singh, 2004:123). Coming to the context of Kashmir, various factors have played pivotal role responsible for the process of social change. In this context, Professor Bashir Ahmad Dabla has emphasized on the impact of other culture on Kashmiri society and called this process as 'Nabrimization'. 
It is evident from the above account and also from the tables presented that old age problems are emerging in Srinagar city. Although, it is not an alarming situation but has become a matter of social concern. These problems are the product of certain social practices and the impact of contemporary changes. Modernization has been a major cause for diminishing traditional values. Family which is the basis and universal social structure of human society has undergone certain change. Despite many positive contributions of modernization for the development of nation like education, introduction of organized sector, commercialization, monetization, urbanization, industrialization, it has at the same time diminished traditions and customs. The social rules in traditional Indian society were based on unity and dependence on family. Every member of the family was dependent on the other, especially the economic dependence. Family in traditional society was more than simply a social unit in which the group was placed above the individual. Among the Kashmiris, the family had a special significance. It is a primary group that is considered to be nearest, dearest and intimate of all groups. This group is always accessible and ready to offer help in times of crisis. Be it a financial or emotional or any other type of help, and there is always a feeling that it is a duty and in fact a privilege to volunteer such a help. The family as a group is more important than the individual members who constitute the group. The main functions of the family mainly were procreation of new members and maintenance of old members but now it has lost this role. The impact of modern society has declined this holism to a certain degree. It is seen in the present study that a section of Kashmiri society has undergone changes owing to the modern waves. This change of traditional family system to modern system is the direct reflection of commercialization, monetization and urbanization of the Indian economy and society. Commercialization is an economic process that includes the development of markets in land, labor, capital and commodities. Increased technological inputs in production and monetization in commodity and labor markets accelerated social change (Banarjee, 1999: 667). Thus commercialization and education put little emphasis on the traditional values and importance is given to consumption level as markers of social status.

The present study highlights the need of the establishment of old age homes. The elders feel that their respect and dignity etc will be secured in such a place. Findings of the present study explore the fact that old age homes/day care centers are need of the hour, especially for the elderly living without their children and having least interaction with neighbors, relatives, and friends etc. Also, in some cases elderly from nuclear families, where there are working women, need such a place for their day and daily care. Tables indicate that the elderly belonging to upper income group need old age homes due to many reasons like loneliness, least interaction and are even ready to pay for these homes. The majority of elderly especially from middle and lower income groups wants to stay with their families. This is the consequence of the fact that the elderly from former group have least interaction with family, neighbours or relatives and thus want to stay anywhere where there is someone who can talk with them. Although the care which they are getting at home from their servants is enough for their sustenance but in order to enjoy their remaining life, it is imperative for them to share their ideologies. Living in old age homes or day care centers will help them to interact with the people of their genre. Thus an old age home, day care centers is the need of Kashmiri society in general. Old age home will not only serve the need of proper care but is a way to entertain and share and make their life happy in a healthy environment.

Need of old age a home is more seen in upper income group than middle and low income groups. The elders of upper income group feel that their respect and dignity etc will be secured in such a place. Old age homes are a necessity in the present day scenario also because the younger generation do not have the time or in many cases the resources to meet their needs (like medical expenses, special food etc). But old age homes should be considered only as a secondary option. Elders in the family are definitely an asset. It is they who can impart the much needed ethical values and code of conduct in the younger generation. Old age homes as an option should be considered only for the betterment of the senior citizens by way of better physical and mental status, greater possibility for social bonding etc. Under no pretext should the aged be made to feel that they are a burden and hence turned away. Builders can also consider allocating a few houses for the senior citizens within an integrated township (at subsidized rates), so that the feeling of isolation goes away while proximity to dear ones is maintained. 


\section{REFERENCES}

[1] Alam, Moneer.2006.Ageing in India: Socio- economic and Health Dimensions, Academic foundation: New Delhi.

[2] Arvind, K.Joshi.2006.Older Persons in India, Serials Publications: New Delhi.

[3] Baidyanath,Saraswati (ed.). 1997. Integration of Endogenous cultural dimension into development, D. K. Print world Pvt. Ltd: New Delhi.

[4] Banerjee, Kakoli.1999. "Gender Stratification and the contemporary marriage market in India", Journal of Family Issues, Vol. 20, No. 5, pp.648-675.

[5] Banerjee, Tapan.2002. Senior citizens of India, Rajat publications: New Delhi.

[6] Bhatia, S (etal). 2007 . A study of health problems and loneliness among the elderly in Chandigarh, Indian Journal of Community Medicine Vol : 32, no : 4.

[7] Biswas, S.K. 1987, 'Dependency and Family Care of the Aged'. In S.K. Biswas, (ed.), Aging in Contemporary India. The Indian Anthropological Society: Calcutta

[8] Branch L, Horowitz A, Carr C. 1989. The implications for everyday life of incident self-reported visual decline among people over age 65 living in the community, The Gerontologist, Vol.29:359-365.

[9] D.Paul, Chawdhry.1992.Ageing and the Aged, Inter India Publications: New Delhi.

[10] Dorothy Smith-Ruiz. 1985. Social Problems and Issues of the Elderly, J Natal Med Assoc.; 77(5): 356.

[11] Gangrade, K.D. 1989. Emerging Conception of aging in India: A Socio-cultural Perspective" in Eastern Anthropologist; 42:151-69.

[12] Gorman M. 1999. Development and the rights of older people. In: Randel J, etal. (ed.). The ageing and development report: poverty, independence and the world's older people. Earth scan Publications: London, Ltd.,pp 3-21.

[13] Guha Roy, S, 1987, 'Demography of Aging: Indian Experience'. In S.K. Biswas, ed., Aging in Contemporary India. The Indian Anthropological Society: Calcutta.

[14] Jindal BL. 1987. Alienation among the ageing males. In: Sharma ML, Dak TM, editorsp. 183-4.

[15] Kumudini, Dandekar. 1996. The Elderly in India, Sage Publications: New Delhi.

[16] M.Z.Khan.1997.Elderly in Metropolis, Inter -India Publications: New Delhi.

[17] P.Krishnan\&K.Mahadevan (ed.).1992.The Elderly Population in Developed and Developing World: Policies, Problems and Perspectives, B.R.Publications: New Delhi.

[18] Pappathi, K.2007. Ageing-scientific perspectives \& social issues, APH publishing house: New Delhi.

[19] Phoebe.S.Liebig\&S.Irudaya, Rajan (ed.).2005.An Ageing India: Perspectives, Prospects \& Policies, Rawat Publications: New Delhi.

[20] R. Isralowitz.2003. Vision Problems of Elderly Immigrants In Israel: A Prospective Study. The Internet Journal of Ophthalmology and Visual Science. Vol 2, No 2.

[21] Rajagopal, Dhar.Chakraborti.2004.The Greying of India: Population Ageing in the context of Asia, Sage Publications: New Delhi.

[22] Rao, D.Bhaskara.2003. World Assembly on Ageing, Discovery publishing house: New Delhi.

[23] Report on Survey of Aged in Kerala 2002-03, Department of Economics \& Statistics, Kerala.

[24] S.Irudaya, Rajan (etal).1999.India's Elderly: Burden or Challenge, Sage Publications: New Delhi.

[25] Saxena, D.P.2006. Sociology of Ageing, Icon publications: New Delhi.

[26] Singer, Milton, 1968, 'The Indian Joint Family in Modern Industry". In Milton Singer and Bernard S. Cohn, eds., Structure and Change in Indian Society. Wenner-Gren Foundation for Anthropological Research: New York.

[27] Sunanda, Rabindarnathan.2006.The Elderly in Urban Indian Families: conflict in solidarity,B.R.Publication: New Delhi. 